\title{
ENTERPRISE UNIONISM IN CRISIS IN JAPAN
}

\author{
Hiromasa Suzuki, Ph.D. \\ PROFESOR DE ECONOMÍA DEL TRABAJO \\ UNIVERSIDAD DE WASEDA \\ masa-suzuki@mbd.ocn.ne.jp
}

\section{Resumen}

Durante las últimas décadas, la tasa de sindicalización en el Japón ha venido descendiendo, al mismo tiempo que se imponen nuevas formas de empleo y prácticas de outsourcing. En este contexto, el autor analiza si los sindicatos pueden seguir siendo considerados legítimos representantes de los trabajadores y si están respondiendo a las aspiraciones de éstos. En la primera parte del trabajo se examinan los logros del sindicalismo en las empresas entre 1945 y 1980, mientras en la segunda se expone las áreas problema identificadas desde que en 1991 las condiciones económicas del Japón cambiaron sustancialmente a raíz de la competencia global y, en consecuencia, las empresas reestructuraron sus actividades, lo que incluyó reducción del empleo y nuevas locaciones en China.

\section{Introduction}

Like in most industrial countries, union density has been declining in Japan during the past two or three decades. The estimated unionization rate stood at $20,2 \%$ of the total employed persons in 2002, that is, merely one out of five workers is now belonging to the organized sector. In 1975, one out of three workers was unionized, putting the total organized population at 12,6 million, while it amounts today to 11,5 million. Each year, official data show that the unionization rate decreases by around $1 \%$ every two years. If we restrict to the private sector, the unionization rate fell to $16,8 \%$, a very low figure at international standard.

Unionization rate typically differs according to the size of the enterprise and the sector of activities. While large enterprises are highly organized thanks to a socalled union shop agreement, in small and medium enterprises, workers are seldom unionized $(1,3 \%$ in enterprises with less than 100 employees in 2002). Similar distinction could also be made by sector; 
while manufacturing and financial sectors show a relatively high unionization after the public service, the services and the construction business are scarcely unionized. At present, there is an ocean of nonunionized sectors with some islands of highly unionized large enterprises.

At the national level, the national federation Rengo participates in many consultative bodies related to economic and social policies but with a diminishing unionization rate, the question of representativeness might be raised in the future.

A more direct question on which this paper would try to focus is whether enterprise unions today could really be considered as the legitimate voice of workers, in view of the declining coverage of unions, of the diversification of forms of employment and new practices of outsourcing. Of course, by definition, unions are the collective voice of workers in collective bargaining. But given the declining rate of unionization and little participatory attitude of many workers to union activities, an important question to be raised is whether an enterprise union has the full support of member workers and if it responds to the aspirations of constituent workers.

In the 1990 s, confronted with the prolonged recession and intensified global competition many Japanese enterprises had to restructure the organization of their activities, including relocating production sites to China, outsourcing and reducing employment. They tended to utilize a growing number of contingent or atypical workers (part-time, contract workers or temporary workers). At the same time, there seemed to be a widespread indifference or dissatisfaction concerning the ef- fects and results of union activities among workers. In part, due to this attitude of member workers, Japanese enterprise unions can no longer mobilize workers for industrial conflicts, even in case of difficult collective bargaining (the last largescale strikes date back to 1975 in the public sector -National Railways- and to 1960 in the private sector -coal mining-).

The first section of this paper will review the achievements of enterprise unions, largely borrowing the assessment of Professor T. Shirai, who literally coined the expression «enterprise unionism» in the 1970's in Japan.

The second section will examine problem areas for enterprise unionism. One cannot be too optimistic for the future of enterprise unionism from the viewpoint of a collective voice of the workers or the basis of industrial democracy.

\section{Achievements of enterprise unionism (1945-1980's)}

According to Professor Shirai, «an enterprise union can be defined as a labor union that organizes regular workers in specific enterprises, establishments or plants and has a complete autonomy of its own management and operation» 1 . Typically, regular workers of a company such as Toshiba, Toyota motors, etc. are organized in one union and negotiate conditions of work and rules at the level of the enterprise. This means that the eligibility for

1. Shirai, T. Japanese industrial relations. Japanese Economy and Labor Series $\mathrm{N}^{\circ} 5$, Japan Institute of Labour, 2000. Also see Shirai, T. Gendai Nihon no Romu Kanri(Personnel Management in Contemporary Japan). 2nd edition. Toyo Keizai Shinposha, 1992. 
membership of the union is limited to regular workers (who have an employment contract without limitation of time), thus excluding part-time workers or people from subcontracting firms. Moreover, those regular workers, when they arrive at the mandatory retirement age will loose the membership, since they will no more be «regular workers».

As to the origin of unions organized at the level of one enterprise, two interpretations have so far been advanced. The first one stresses the link between Sangyo Hokkokukai (movement of workers for war efforts), which had been organized at plant/enterprise level ${ }^{2}$. The spectacular wave of unionization (1945-1946) would merely overtake the existing Sanpo structure.

The second school of historians denies the link between the two, contending that the Sanpo movement had little real impacts at the level of plants and they point to the fact that plant/enterprise was the usual level where decisions concerning labor matters were taken.

As a matter of fact, whatever might be the direct origin, enterprises were the only viable unit in view of a lack of national union leaders and the postwar economic and social disruption. It is worthy to note that prewar labor unions, a rather shortlived experience, were organized on the model of craft unions in 1912 (Yuai kai) and had a certain influence after WWI but afterwards were severely suppressed by the government.

2. For instance, Nakamura, T. The postwar Japanese economy. Tokyo University Press, 1995.
Between 1945 and 1955, nascent enterprise unions survived ideological divisions and consolidated their institutional basis in the private sector ${ }^{3}$. After the end of the Korean War, the logic of enterprise unionism is easy to capture. In the private sector, management, which recovered their necessary authority, tried to avoid any presence of «outsiders» in union business and collective bargaining. In many cases, a union shop agreement was concluded at that time in large enterprises in order to eliminate a second union (scare of radical activists). From 1955 to the 1980s, enterprise unionism was solidly institutionalized so that it became the feature of Japanese industrial relations.

Most enterprise unions join industrial federations and national federations, which are strictly coordinating bodies. The major activities of unions focus on wage negotiation rounds called Spring Offensive. Of interest at this juncture is the evaluation of the Japanese industrial relations dominated by enterprise unionism made by professor T. Shirai, who is not only a most respected industrial relations scholar but also, to some extent, a practitioner of labor issues (he was member of the Central Labor Commission, and president of the Central Labor Standard Council, at the Ministry of Labor). As such, he can be considered as the finest observer of the development of the Japanese industrial relations.

Professor Shirai gives very high marks to the Japanese industrial relations on the following points ${ }^{4}$.

3. Koshiro, K. A fifty year history of industry and labor in postwar Japan. Japanese Economy and Labor Series $\mathrm{N}^{\circ} 6$, Japan Institute of Labor, 2000.

4. Shirai. Op. cit. pp. 121-142. 


\section{a) Contribution to economic growth}

After twenty years of a turbulent period, a high growth period from 1965 changed the labor market condition to favor unions for bargaining position. Enterprise unions facilitated the technological development and the economic adjustment process after the first oil crisis.

\section{b) Support for an efficient Human Resource Management}

Regular employees in Japanese enterprises used to work on the basis of a wide job cluster through the so-called lifetime employment system. Enterprise unions did not employ restrictive labor practices, therefore instrumental to a great internal mobility and flexibility.

\section{c) Distribution of the benefits of increased productivity}

Through the mechanism of annual Spring Offensive, the benefits of increased productivity were distributed in the form of an improvement of real wages, shorter working hours and strengthened job security.

\section{d) Without inflation and unemployment}

In Japan, collective bargaining proved to be highly responsive to the changing economic environment. This responsiveness of the Japanese industrial relations comes from a common perception of the importance of the prosperity of the enterprise that is shared by the management and the labor. Thanks to this shared perception, Japanese industrial relations could pursue the improvement of employment and working conditions without inflation (during the 1970s) and unemployment (1980s).

\section{e) Development of industrial democracy}

Through the diffusion of collective bargaining practices and collective agreements, matters formerly decided by management became the subject of consultations and negotiations. Rank and file workers were given the possibility to communicate with union leaders in the system of enterprise unionism.

This bird view evaluation is interesting in that Professor Shirai has an extensive knowledge of historical facts and he personally witnessed prewar conditions.

In more specific terms, we could summarize the achievements of enterprise unionism by main issues.

\subsection{Intensive information sharing}

In the 1950s, when the Japanese Productivity Center was created, the economic leaders like Prof. I. Nakayama, recommended the creation of a joint labor-management consultation machinery to learn from «harmonious industrial relations in the US» 5 . It was to overcome the conflictual industrial relations, which was predominant in Japan at that time.

In the private sector, a joint consultation machinery was adopted very quickly in most large private enterprises. At the beginning, maybe collective bargaining and joint consultations could have different functions but, since within a specific enterprise the same persons sat in both committees, the demarcation line became blurred. What emerged from the diffusion of joint consultations was an intensive

5. Nitta, M. Henka no naka no Koyo System (Changing employment relations). Tokyo University Press, 2003. 
channel of information sharing between management and union. Exchange of information and consultation on diverse subjects such as safety, QC circles, hours of work, wage systems, procedures of HRM, helped to create a favorable climate conducive to harmonious industrial relations with the passage of time.

\subsection{Employment protection}

The popular expression «lifetime commitment» appears to have been coined by a foreign consultant, J. Abegglen, whose book «The Japanese Factory» was published in 1958. The expression was translated into Japanese as «lifetime employment». Prof. M. Nitta draws our attention to that period, because Japanese businesses and unions wanted to adopt no dismissal promise as a social norm ${ }^{6}$.

After a period of industrial strife between 1945-1955 whereby the main cause for long work stoppage was always collective dismissals or the closure of factories, case law gradually created the theory of abuse of right in employment contracts. Indeed, the Labor Standard Law was completely silent on the termination of employment, except for prior notice obligation. The Court turned to the original interpretation of contract law. Considering that at that period, the loss of employment had a critical effect to the workers and their close family, the Court elaborated the theory of abuse of right, whereby the enterprise retains the right to

6. Ibid. Also see: Nakamura, K. and Nitta, M. Developments in industrial relations and human resource practices in Japan. In Locke, R.; Kochan, T. and Piore, M. (eds.). Employment relations in a changing world economy. MIT Press, 1995. terminate an employment contract, but should prove that every effort was made to avoid dismissals ${ }^{7}$.

Case after case, conditions and procedures for valid dismissals were elaborated so that by 1970 , a case law against unjustified dismissal was firmly established. In so doing, labor unions were most instrumental. In fact, by the time Abegglen's book appeared, large enterprises and unions recognized the paramount importance of employment security ${ }^{8}$.

\subsection{Single enterprise union}

During the turbulent period of industrial strife (1945-1955), long conflicts involved divisions of enterprise unions. A wellknown case is that of Nissan (1953). Moderate elements of employees -probably supported by the company- split away from the main union during conflicts. The first union rapidly lost its members and became a minority union. The company then passed a collective agreement with the moderate union so as to eliminate the radicalized old union.

This type of conflict involved a lot of violence and divisions followed by long Court procedures. Therefore, enterprises became quite sensitive to the eventual division of unions or to the intervention of outsiders. In most large enterprises, a union shop agreement was adopted so as to avoid any attempt to create a second union.

7. Sugeno, K. Shin Koyo shakai no Ho (Law in a society of employment). New ed. Yuhikaku, 2002.

8. Nitta. Op. cit. 


\subsection{Sharing union leaders' experience}

Information sharing for a common perception between management and union often provided a terrain for a generational dialogue.

In fact, most of top executives in their young days, used to serve as shop steward, often as full-time union leaders for several years. After all, union activities are an excellent opportunity to learn the organization of the enterprise and to reveal someone's capacity of leadership.

In most cases, promising young staff cease to serve union duties because they get a promotion to managerial position, which would often disqualify from being member of the union ${ }^{9}$. Some union leaders chose to stay in the union activities (for instance Mr. E. Washio, former president of the Rengo). The very fact that top managers used to serve as union shop stewards tended to facilitate a mutual understanding, which is a necessary condition to build a common perception.

Thus, the Japanese industrial relation system based on enterprise unionism did achieve an important progress towards the improvement of employment and working conditions and industrial democracy by the end of the 1980 s, so that it could be qualified as harmonious and responsive to changes in the economic climate. At the same time, several structural weaknesses of the Japanese system became clear.

9. Inagami, T. (ed.). Seijuku Shakai no naka no Kigyobetsu Kumiai (Enterprises unions in a mature society). Japan Institute of Labor, 1995. This study is based on a large survey carried out by the Rengo. See particularly pp. 79-166 (analyzed by Fujimura, H.).
Firstly, there was a clear lack of coordination and negotiation at the industry level. With exception of some major industrial unions (Yuai-Zensen domei: Federation of textile workers, Tekko Roren: Federation of Steel workers, Denki Rengo: Federation of Electric machinery workers), industrial unions played a very limited role indeed. Even during the heyday of the Spring Offensive, most industrial unions could not formulate precise demands, since each enterprise union was autonomous and independent. Due to this inaction at the industry level, a division between the organized sector (large enterprises) and the vast non-organized sectors (small enterprises, services) became widespread. The result was a dual structure of the labor market, in which the organized sector would enjoy the protection of collective bargaining, while the non-organized sector was only mediated by the market mechanism.

A second major weakness of enterprise unionism relates to the handling and management of union business. Although many meetings take place at the shop floor level, there is a latent criticism that enterprise unions do not listen to individual complaints, particularly those in a vulnerable position. For instance, in many large enterprises, geographical relocation (internal mobility) of workers is part of a package concerning employment security. Management and union are rather insensitive to individual family problems (situation of the spouse or old-age parents). In most cases, union officials do not attach sufficient attention to individual rights, as they prefer to focus on the maximization of wage increases. 


\section{Eroding Edifice in the 1990s}

Since 1991, the economic climate of Japan has changed dramatically due to, among other things, the increasing pressure for global competition and the collapse of the bubble economy. Pressure for global competition was noticeable in various ways. Large manufacturing enterprises (for instance those in electric industry) had to shift their production to lower-cost countries, in particular to mainland China, with resulting employment reductions in Japan. More significantly from industrial relations point of view, protected sectors such as telecommunications, insurance and banking had to lift protection under competitive pressure. For instance, the telephone giant NTT was privatized in 1984 and has had several waves of reorganization. NTT and the large banks used to provide a model of stable employment relations (long-term employment, seniority wages and strong enterprise union) but they could no more guarantee such a long-term commitment to workers.

The burst of the bubble economy in 1991 brought a spiral of asset depreciation, in particular in real estate. Each year, the mortgage for large loans given by banks lost market value with an appalling speed and many construction companies went out of business. The cornerstone of the Japanese economic system -the main bank system- literally fell down by the weight of ever-growing bad loans.

Together with this slumping domestic consumption and investment, there was also the increase of very cheap imported products in daily consumer products. As a result, the price level remained very stable during the first years and began to decrease at the end of the 1990s (from 1988 to 2001 , the CPI registered a very minor increase of $0,6 \%$ over the period, an implicit deflator of $-0,2 \%$ and a wholesale index of $-1,1 \%)$.

In this morose domestic conditions, many manufacturing enterprises increased the purchase of overseas product (outsourcing) and also direct investment for off-shore production, mostly to mainland China. The high level of the yen against the US dollar, to which many Asian currencies were pegged, was a considerable handicap for Japanese manufacturers.

In retail trade, an apparel shop called «Uniclo» made a spectacular jump thanks to cheap but fashionable products made in China. Thus, consumer prices have shown a steady decline. In a way, the move towards a globalized economy has resulted in strong tensions with the existing Japanese economic institutions. This sudden change in the economic climate put a strong pressure for the management of enterprises and enterprise unionism. In 1989 , at the national level, the long awaited unification of labor movements was achieved by the creation of Rengo (Japan Trade Union Confederation), which accounted for some 8 million members. It was intended to activate the labor movements at different levels.

Ironically, it was the time when the economic climate was changing. The development of the present decade has shown, instead of a progress in many fields, an erosion of the achievements of the previous period ${ }^{10}$.

10. As a sign of the diminishing influence of union movements in Japan, one might indicate that the main employers 'federation (Japan Federation of Employers' Association) was merged 
Union density in the 1990s and after

\begin{tabular}{|c|c|c|c|c|}
\hline Years & $\begin{array}{c}\text { Total } \\
\text { Membership }\end{array}$ & Density & $\begin{array}{c}\text { of which: } \\
\text { enterprise with } \\
\mathbf{1 0 0 0} \text { employees } \\
\text { and more }\end{array}$ & $\begin{array}{c}\text { enterprise with } \\
\mathbf{1 0 0 - 2 9 9} \\
\text { employees }\end{array}$ \\
\hline 1990 & 12265 & $25,2 \%$ & $61,0 \%$ & $24,0 \%$ \\
1995 & 12614 & $23,8 \%$ & $59,9 \%$ & $21,2 \%$ \\
2000 & 11539 & $21,5 \%$ & $54,2 \%$ & $18,8 \%$ \\
2002 & 10801 & $20,2 \%$ & $54,8 \%$ & $16,8 \%$ \\
\hline
\end{tabular}

Source: Ministry of Health, Labor and Welfare Rodokumiai Kiso Chosa (Basic Survey of Trade Unions).

\subsection{Decline of unionization hits strongholds of enterprise unionism}

As already mentioned, the overall unionization rate has continued to decline in many enterprises, but more significantly in the sector which used to be the stronghold of the union movements. As is shown by the following table, the total number or union members decreased by 1,5 million and 5 percentage points from 1990 to 2002. Small and medium enterprises were more severely affected than larger enterprises by the loss. In fact, enterprise unions were not the same everywhere; some unions were more active and more committed to collective bargaining than others.

with the Japan Federation of Economic Organizations in 2002 as the Japan Business Federation. The former performed the role of coordinating body of large business in labor and industrial relations. In a similar movement, the Ministry of Labor was merged with the Ministry of Health and Welfare in 2001. There is no more a department specifically dealing with industrial relations problems. It so appears that labor and industrial relations are no more national concerns, to put it mildly.
In recent publications, Inagami and Ide identify different types of unions in terms of participation in management ${ }^{11}$. Enterprise unions may be vocal in consultation machinery and collective bargaining, while others would sit at consultation meetings without really participating or exchanging important information for the union concerned. The former type of participation in management could be found in manufacturing, wholesale, restaurants and transport, while the latter was found in the construction and financial sector.

Active unions were found in such industrial federation as steel, electric machinery, metal, telecommunications, textile and retail (large department stores). These unions used to provide most of the national union leaders. The decline of unionization hit directly those leading sectors for the labor movement, due to the fact that they belong mainly to the manufacturing industry exposed to global competition. In a recent econometrical study,

11. Inagami. Op. cit. pp. 235-269. 
Tsuru indicated that the decline in unionization was mainly due to the failure to organize new enterprises and industries, which is somehow contrary to the traditional view ${ }^{12}$.

Between 1995 and 2002, the Denki Rengo (Federation of electric machinery workers' union) lost some 100 thousands members or $13 \%$. Steel enterprises used to be a pattern setter for all wage negotiation rounds. Their membership went down from 180 thousands in 1995 to 131 thousands in 2002. Accordingly, the union leadership seems to shift from the private manufacturing sector to a more protected or dynamic sector such as the electricity or automobile sector. They are reputed to be rather moderate in union actions.

\subsection{Annual spring offensive loosing momentum}

The main activity of Japanese unions, be it at enterprise level or industrial or national level, has been and still is wage negotiations, which take place in spring. It was initiated in 1955 by large unions in order to cover the weaknesses of enterprise unionism, and unions tried to coordinate all annual wage negotiations in spring. Spring wage negotiations became an important economic and social event by which most enterprises and organizations adjusted their wage level according to the price increase, productivity rise and profit level. Thanks to this mechanism, the wage level of Japanese workers has recorded a spectacular increase up to the 1980s.

12. Tsuru, T. Roshikankei no non unionka (Non unionization of industrial relations). Toyo Keizai Shimposha, 2002. pp. 85-121.
But during the 1990s, and particularly since 1995 , the real wage adjustment was very small, less than one percent, excluding the personal increment element. Because of the stagnation of wage negotiations, unions' leaders were in a delicate position. Rank and file workers tended to show high expectations for wage increases but the result of the negotiations was extremely poor. The main justification of high union fee ( 1 to $1,5 \%$ of the monthly salary automatically deducted from members' pay) is still the improvement of wages and other conditions of work.

Unfortunately, so far wage negotiations have exclusively focused on the average increase or the monetary amount of wages, excluding other items as the reduction of working hours, retirement benefits or private pension programs (which are dealt with in separate negotiations). In a time of low growth period, enterprise unionism seems to be in need to find other objectives than wage adjustments, which may receive support or involvement of their members. Such new major objectives do not appear today on the horizon.

\subsection{Diversification of forms of employment: diluting workers' community at the enterprise level}

The main justification of enterprise unionism resides in the notion of belonging to the same enterprise community. The relationship between management and union is basically prescribed by the mutual understanding that they are in the same boat and the survival or prosperity is the ultimate goal. The same logic applies to union officials and rank-and-file employees. This is the reason why regular employees of the enterprise exclusively form enterprise unions. 
As in many countries, there is a growing tendency in Japan to employ atypical or contingent workers. According to data from the Labor Force Survey, in 2002, regular employees (those who hold a contract of long-term duration and who work on a full-time basis) accounted for 70,6\% of all workers (excluding managerial position) and non-regular employees accounted for $29,4 \%$. The ratio of non-regular workers was steadily increasing from 1986 when non-regular workers amounted to $16 \%$. Most of the increases were attributable to the growth of part-time/ casual employment. These increasing numbers of part-time workers are mostly left outside the enterprise unions ${ }^{13}$. The same rule of exclusion applies to temporary or contract workers.

In addition, it is rather common in Japanese manufacturing/building industries to resort to sub-contracting (sub-contractors) in some production processes. Employees of sub-contractors often work in the premises of the mother enterprise. They are, of course, outside the scope of enterprise unions, unless workers of subcontractors are organized in a general union (the automobile union is a wellknown exception).

On top of this, large enterprises like Matsushita or Canon have many factories and research centers scattered all over Japan and overseas. The main point of these developments is that the workers' sense of community at the level of the enterprise is now diluting. Core workers or «regular employees» are sometimes a minority and isolated.

13. In 2002, the estimated rate of part-time workers was nearly $2,7 \%$.

\subsection{Limit of information-sharing and consultation}

In most large enterprises, different channels of consultation and negotiation have been so far preserved. Management and unions meet very frequently (often once a month) to discuss issues related to employment such as financial state, production schedule and restructuring, relocation of staff, changes in wage systems or employment reductions ${ }^{14}$. At best, union officials have access to some confidential information such as investment and production strategy or reorganization of the structure and may have a certain influence on some strategic decisions. But in recent years, many enterprises troubled by the slumping domestic consumption have resorted to offshore production and a reduction of employment by natural attrition and voluntary retirement. The logic of the management appears much stronger than that of unions. Moreover, it is quite rare that enterprise unions could oppose the employment of part-time or temporary workers.

To some extent, in a difficult economic climate, the limit of information sharing and consultation between management and unions becomes apparent, although unions might claim that they have avoided a massive dismissal of regular employees and worsening of working conditions.

14. Rengo Soken: Rodo Kumiai no Mirai o Saguru (In search for the future of unions). In 638 union surveyed, $83 \%$ had a formal consultation machinery in 2000 . 


\subsection{Distance between union leaders and members}

Thanks to union shop agreements, almost all regular employees are members of the enterprise union. Joining a union is not a voluntary act of the employees. Hence, it is inevitable that there is a cleavage between union leaders and rank-and file workers. In recent years, many unions set out union identity surveys to answer the criticism that member employees were little interested in union activities and that the image of the union was old-fashioned and bureaucratic. Most surveys carried out by unions showed that while members felt, in majority, the activities of the unions useful, they were rather reluctant to actively participate to union movements. For instance, the latest survey of the Denki Rengo (Electric Machinery Workers' Union) covering 20 thousands members showed that, although the majority thought it useful to have a union, they felt that unions conceded to the management $(72,3 \%)^{15}$. One out of four respondent participated actively to union meetings (gave their opinion) and a considerable portion of members viewed union involvement as burdensome. An overall image was that members were distant observers of their unions, and view the union as not really reliable in case of serious matters.

H. Fujimura, using a large survey of the Rengo, recently analyzed the profile of unions' leaders ${ }^{16}$. As a whole, the president of the union was male, and on average 44,8 years old, with long years of service (more than 20 years) but the ex-

15. Denki Rengo Chosajiho $\mathrm{N}^{\circ} 340$, July 2003.

16. In Inagami. Op. cit. pp. 100-131. perience in union business was limited ( 7,1 years). In the case of secretary general, he was 39,7 years old with only 4,5 years or union experience. Once the term of presidency finished, they go back to employee's status. In large enterprises, half of ex-union presidents occupied a management position when they retired from their union position.

To some extent, the profile of union leaders shows an ambivalent position: on the one hand, they are temporary full-time union officials representing union members, but at the same time they know that their union position is temporary, since they will go back to an enterprise position. It is not certain that they chose unions duties because of personal convictions. With some exceptions (particularly in very large enterprises), union leaders are not full-time, career officials of the union. This may at least partly explain why rank-and-file workers consider union leaders not really reliable in case of serious matters.

\section{Some avenues to rebuild legitimacy for enterprise unionism}

After WWII, enterprise unionism was born almost by chance in Japan, because the enterprise was a natural locus for collective voice and negotiations. More than half a century later, the Japanese enterprise unionism is facing formidable problems of routinization and a difficult economic climate.

As we have seen, problem areas are numerous and often delicate to handle. But we should not go too far in this pessimistic view. Indeed, there are many assets of enterprise unionism. 
First of all, enterprise unions are financially healthy. As is mentioned, unionization is close to $100 \%$ as far as regular employees in large enterprises are concerned and union fees (roughly 1 to $1,5 \%$ of monthly wages) are deducted from the wage bill and automatically paid to the union through check-off practices. On this sum, the enterprise union retains $80-85 \%$, and the remaining goes to the industrial union or national federation.

This is definitely a privileged situation compared to other countries, even though the remuneration of union leaders who are on temporary detachment is entirely covered by union fees.

Enterprise unions benefit from the existing labor-management consultation machinery as well as collective bargaining. In spite of criticism of routine, most joint consultation and collective bargaining have survived, just as the annual spring wage negotiation. Through joint consultation and negotiation, information sharing and sometimes close consultation are secured in most cases. Therefore, unions have an ample possibility to discuss with the management in relation, for instance, to major changes in employment practices and employment reductions. Rank and file members seem to mildly support union leaders even though they would not often participate to union activities. This distant support is better than overt criticism and union leaders and union leaders can conduct negotiations on behalf of their members.

In addition, some industrial federations such as Ui-Zensen or Denki Rengo are strong and take leadership for union business. If an industrial federation is dynamic and capable of guiding enterprise unions, the latter may overcome some of the weaknesses of enterprise unionism. For instance, they may submit a common minimum demand for wage level (minimum wage for certain benchmark workers) and hours of work across the industry during the spring negotiation.

Given such assets, it seems that there are several avenues to rebuilding the momentum of enterprise unionism today.

a) Enterprise unions are in need to fix a major objective capable of mobilizing member employees. So far, unions have taken it for granted that wage increases would respond to the expectations of rank and file workers. In time of a difficult economic climate, it is self evident that unions would not get a large wage improvement. A modest perspective of real wage increment is no longer an objective for which rank and file workers would willingly be mobilized.

b) In the area of employment and conditions of work, employment security and private pensions (including retirement benefits) seem today to constitute the major preoccupation of employees. It may well be a target to which member workers feel quite concerned.

For young workers, formal training and a certain guarantee of career prospect may also offer attraction.

c) Strengthening the leadership of union officials is also a possibility and a necessity. In most enterprise unions, the position of union leaders has been generally considered as temporary. Therefore, temporary union leaders would not pursue negotiations aggressively 
and they may be tempted to jeopardize their professional career. In this respect, officials of the industrial federation should behave as advisers and somehow guide the negotiation process. In terms of education and training of future union leaders, there is much to be done by industrial federations.

Finally, it seems important to increase the basis of workers' community, includ- ing atypical workers and middle management positions (they are more akin to workers than executives). So far, enterprise unions have modestly tried to increase membership (financial benefits), but the most important consideration should be to rebuild cohesion and the solidarity of workers' community, although the logic of global competition has so far pressed toward the opposite direction. 